\title{
TRANSFORMASI GERAKAN TAREKAT SYAFAWIYAH DARI TEOLOGIS KE POLITIS
}

\author{
Abdul Syukur \\ IAIN Raden Intan Lampung \\ abdul_syukur@iainradenintan.ac.id
}

\begin{abstract}
Abstrak
Gerakan tarekat Syafawi di Iran semula bertujuan untuk membentuk kesalehan pengikutnya dan memerangi ahli bid'ah. Namun pada gilirannya tarekat ini menjadi gerakan sosial yang mengkritisi penguasa yang hidup dalam kemewahan dan jauh dari kesalehan. Selain dari itu, Kondisi sosial-politik di Iran juga mendorong tarekat Syafawi yang semula merupakan gerakan keagamaan-politik menjadi gerakan politikkeagamaan. Doktrin Mahdiisme dan doktrin Imamah dalam ajaran Syi'ah Dua belas dijadikan landasan legitimasi oleh para pemimpin Tarekat Syafawi untuk mewujudkan ambisi kekuasaan dan cita-cita politikkeagamaan mereka. Hasilnya, gerakan politik-keagamaan kaum Tarekat Syafawi memiliki pengaruhnya yang cukup luas di Iran, dan puncaknya membentuk pasukan Qizilba serta mendirikan Dinasti Safawi di Iran sejak tahun 1501-1736. Setelah berdirinya Republik Islam Iran tahun 1979, Syi'ah Dua belas masih dipertahankan sebagai mazhab negara dalam sistem religio-politik yang diwadahi oleh Wilayat al-Faqih.
\end{abstract}

\section{Abstract}

TRANSFORMATION OF TARIQA SYAFAWIYAH'S MOVEMENT: FROM THEOLOGICAL TO POLITICAL. The Former Movement of Safavid orders in Iran originally had been intended to establish piety among its followers and to combat heresy. But this congregation eventually turned into a social movement that criticized the rulers living in luxury and away from piety. Thus, it was the Socio-political conditions in Iran that encouraged the turning of original congregations of Safavid from religious-political movement into a political - religious movement. Mahdiism doctrines and the doctrine of Imamate of the Twelver of Shi'ism had been premised by the 
Safavid congregation leaders to realize their the ambition to power and their political, religious ideas. As a result, the political-religious movement of the Safavid Tariqa experienced a fairly wide influence in Iran which culminated in the formation of Qizilba forces and the establishment of the Safavid dynasty in Iran between the year 1501 to 1736. After the foundation of the Islamic Republic of Iran in 1979, the Twelver Shiites was still maintained as a state school in the religio-political system and was accommodated in the concept of Wilayat al-Faqih.

Kata kunci: zuhud; imamah; tarekat Syafawi; Syi'ah Dua belas.

\section{A. pendahuluan}

Dalam perspektif pemikiran politik Islam dinyatakan, bahwa Islam tidak memisahkan agama dari politik dan politik pun memerlukan legitimasi agama. Hal demikian kemudian di dalam Islam dikenal istilah "Islām huwa ad-din wa ad-daulah". Istilah tersebut, dalam perspektif pemikiran politik Islam disepakati oleh kaum Syi'ah dan kaum Sunni bahwa secara konseptual-doktrinal, Islam tidak dapat terlepas dari agama dan politik. Namun secara praksis, kaum Sunni memisahkan agama dari politik dalam praktik politik dengan sistem khiläfah. Sebaliknya, kaum Syi'ah meyakini bahwa doktrin mempercayai pemimpin Islam (imāmah) merupakan masalah teologis dan sekaligus masuk ke dalam wilayah kepentingan politik. Keyakinan atas doktrin imāmah, sehingga secara praksis kaum Syi'ah berusaha menerapkan sistem imāmah (religio-politik) dalam Islam. Mereka meyakini bahwa Islam tidak terpisahkan dari kepentingan agama dan politik sebab politik dan agama menyatu dan saling berhubungan untuk mewujudkan kepentingan kekuasaan dan syiar Islam (dakwah) bagi umat Islam.

Keyakinan kaum Syi'ah tentang doktrin imāmah kemudian mereka berusaha mengimplementasikannya dalam kehidupan sistem religio-politik. Dalam sejarah dibuktikan, bahwa praktik politik Islam yang pernah mereka wujudkan di antaranya adalah pengalaman politik-keagamaan kaum Terekat Syafawi di Persia (kini: Iran) sejak abad ke-13 sampai abad ke $18 \mathrm{M}$.

Gerakan politik-keagamaan kaum Tarekat Syafawi terjadi ketika dunia Islam tengah memasuki periode pertengahan (1250- 
1800 M). Gerakan Tarekat Syafawi muncul pada abad ke-13 M di Ardabil, sebuah kota di Azerbeyjan, ${ }^{1}$ wilayah Iran bagian Barat. ${ }^{2}$ Ardabil pada saat itu merupakan wilayah kekuasaan Qarā Qiyunlu yang berasal dari suku Turki yang menganut Syi'ah. Pendiri Tarekat Syafawi adalah Safi ad-Din (1252-1334). ${ }^{3}$

Safi ad-Din ialah murid sekaligus menantu Syaikh Taj ad-Din Ibrāhim Zahidi al-Gilani (1216 - 1301). ${ }^{4}$ Setelah Taj ad-Dỉn wafat, Safi ad-Din meneruskan kepemimpinan tarekat yang telah diajarkan oleh gurunya, dan perkumpulan tarekat itu diberi nama Tarekat Syafawi. Bahkan nama Syafawi dipertahankan hingga berdirinya Dinasti Syafawi di Persia (Iran) sejak 1501 hingga 1736.

Gerakan Tarekat Syafawi pada masa awal masih bercorak keagamaan murni. Tetapi, karena kondisi sosialyang mendukungnya dan doktrin Syi'ah yang memotivasi kaum Syafawi, kemudian mereka merubah corak pemikiran keagamaan kepada pemikiran politik-keagamaan dalam gerakan Tarekat Syafawi di Iran.

Pada masa awalnya, Tarekat Syafawi berbentuk pengajian tasawuf murni yang bersifat lokal, ${ }^{5}$ yang bertujuan menanamkan ajaran-ajaran Sufistik dan kesalehan sebagai bagian yang terpenting dalam tasawuf, ${ }^{6}$ sehingga para pengikut (murid) tarekat ini taat dan teguh menjalani ajaran agamanya.

Ketika gerakan Tarekat Syafawyah masih dibidang keagamaan memiliki tujuan untuk memerangi orang-orang ingkar dan golongan yang mereka pandang ahli bid'ah.7 Selanjutnya gerakan tarekat

${ }^{1}$ C.E. Bosworth, The Islamic Dinasties: A Cronological and Geneological Handbook, (Edinburgh: Edinburgh University Press, 1970), h. 72.

2Julian Baldick, Mystical Islam: An Introduction to Sufism, (New York \& London: New York University Press, 1989), h. 109.

${ }^{3}$ Harun Nasution, Islam Ditinjau dari Berbagai Aspeknya, (Jakarta: UI Press,1984), Jilid I, h. 84.

${ }^{4}$ Adel Allouche, The Origins and Develovment of The Ottoman Safavid Conflict (1500-1555), (Michigan: Michigan University Micro Film Internasional, 1980), h. 96.

5Hamka, Sejarah Umat Islam, (Jakarta: Bulan Bintang, 1981), Jilid III, h. 60.

${ }^{6}$ Kamil Mustafa al-Shaibi, Sufism and Shi'isme, (England: Biddle Ltd., Guilford \& King's Lynn, 1991), Cet. I, h.307.

${ }^{7}$ Hamka, Sejarah..., h. 60, Nasution, Islam...,h. 79; dan Nouruzzaman asShiddiqi, Jeram-jeram Peradaban Islam, (Yogyakarta: Pustaka Pelajar, 1996), Cet. I, h. 117-118. 
ini berubah menjadi gerakan politik yang fanatik dan menentang setiap orang yang bermazhab selain Syi'ah Dua belas. Mereka membentuk pasukan Qizilbaș dan menyebarkan propaganda doktrin Syi'ah Dua belas dengan cara-cara yang radikal dan revolusioner di tengah masyarakat sehingga terkenal dengan nama gerakan Mahdi (Messianic Mahdiism). ${ }^{8}$ Tujuan gerakan Mahdiism untuk menegakkan keadilan sambil menunggu kedatangan imam al-Mahdi al-Muntaẓar sebagai penegak keadilan.

Para pemimpin Tarekat Syafawi selama bergerak di bidang keagamaan berturut-turut dipimpin oleh Safi ad-Dỉn, Sadr ad-Dỉn, Khawajah Ali, dan Ibrahim Ibnu Khawajah Ali. Ketika bergerak di bidang politik dipimpin oleh Junaid, Haidar dan Ismail. Gerakan Tarekat Syafawi menjadi besar pengaruhnya di wilayah Persia, Syiria dan Anatolia. ${ }^{9}$ Pimpinan tarekat ini pada tingkat pusat di Ardabil disebut syaikh, dan wakilnya di wilayah-wilayah luar Ardabil diberi gelar khalāfah. ${ }^{10}$ Dengan demikian, khilāfah adalah wakil syaikh.

Kondisi sosio-politik terutama, di samping sosio-kultural dan sisio-keagamaan merupakan faktor-faktor yang mempengaruhi gerakan kaum Tarekat Syafawi dalam menyebarkan ajaran tarekatnya. Oleh sebab itu, tarekat ini memandang penting peranan politik, baik disebabkan oleh faktor internal maupun eksternal. Ketika tarekat ini memasuki bidang politik berubah menjadi gerakan politik yang fanatik dan menentang setiap orang yang bermazhab selain Syi'ah Dua belas di Iran.

Gerakan TarekatSyafawi dibidang politik dengan menamakan gerakan Mahdi memperoleh pengarauh yang kuat dan luas di Persia, Syiria, dan Anatolia. Gerakan Mahdi ini berhasil mengalahkan golongan yang berkuasa di Persia seperti: Timur Lenk (Dinasti Timuriah), Qara Qiyunlu (Penganut Syi’ah), dan Al Qiyunlu (Penganut Sunni). Akhirnya gerakan Mahdi kaum Syafawi yang bersumber dari doktrin imāmah Syi'ah 12 (Religio-politik) berhasil mengalahkan

\footnotetext{
${ }^{8}$ Muslih Fathoni, Faham Mahdi Syi'ah dan Ahmadiyah dalam Perspektif, (Jakarta: Grafindo Persada, 1994), Cet. I, h. 3-48.

${ }^{9}$ Baldick, Op. Cit., h. 110-111; dan M. Ira Lapidus, A History of Islamic Sociaty, (Cambridge: Cambridge University Press, 1988), h. 265.

${ }^{10}$ Hamka, Sejarah Umat..., h. 60; dan Hamka, Sejarah Tasawuf Perkembangan dan Pemurniannya, (Jakarta: Pustaka Panjimas, 1984), h. 167.
} 
penguasa Persia sekaligus menyebarkan dan melembagakan doktrin syi'ah 12 sebagai mazhab resmi negara kerajaan Safawi (1501-1736). ${ }^{11}$

Sebagai organisasai keagamaan (dakwah) tarekat dapat dijadikan institusi politik-dakwah dengan tujuan guna menyebarkan Islam sekaligus meraih cita-cita politik dalam mengembangkan ajaran agama Islam di tengah kehidupan sosial, baik kehidupan sosial-keagamaan maupun sosial-politik (yakni sistem religio-politik Islam) yang dilakukan kaum Tarekat Syafawi. Organisasi tarekat sekaligus sebagai institusi politik-dakwah kaum Tarekat Syafawi selain berfungsi untuk memudahkan konsolidasi dan penyebaran doktrin tarekat itu bagi pengikutnya di tengah masyarakat, juga sekaligus untuk meningkatkan prestise kaum Tarekat Syafawi di hadapan penguasa dan di tengah masayarakat.

Organisasi Tarekat Syafawi di dalamnya mengandung unsur-unsur: guru/pimpinan tarekat (mursyid/syaikh) dan wakil syaikh di namakan khaläfah, pengikut syaikh disebut murid/darwis, ribat/ zawiyah (pondokan), petunjuk tehnik pelaksanaan (zikir, do'a, dan wirid), bai'at, kekeluargaan dan persaudaraan (ukhuwah), ijazah, dan silsilah. ${ }^{12}$ Keenam unsur ini merupakan sistem tarekat yang dapat menghantarkan tujuan tarekat dalam penyebaran Islam dan pencitraan cita-cita politik kaum Tarekat Syafawi di hadapan para pengikut dan simpatisan Tarekat Syafawi khususnya dan masyarakat pada umumnya.

Kemudian timbul permasalahan pokok yang mendasar dalam pembahasan ini, adalah: "Bagaimana praktik politikkeagamaan dalam Islam yang dilakukan oleh kaum Tarekat Syafawi untuk menyiarkan Islam dan mewujudkan cita-cita politik mereka di Iran?"

Untuk menjawab permasalahan di atas, perlu dibahas dengan menggunakan jenis penelitian kepustakaan (library research $)^{13}$ sebab membahas pengalaman sejarah pemikiran dan praktik politik-

\footnotetext{
${ }^{11}$ Allauche, The Origins ..., h. 130-131; dan Philip K. Hitti, The History of The Arabs, (London: Macmillan, 1979), h. 703.

${ }^{12} \mathrm{Abu}$ Bakar Aceh, Pengantar Imu Tarekat Kajian Historis tentang Misitik, (Solo: Ramadhoni, 1992), Cet. VII, h. 236.

${ }^{13}$ Hadari Nawawi, Metode Penelitian Bidang Sosial, (Yogyakarta: UGM Press, 1993), Cet.VI, h. 30.
} 
keagamaan yang pernah dilakukan oleh kaum Tarekat Syafawi di Iran tergolong penelitian sejarah dan penelitian sejarah termasuk jenis penelitian kepustakaan. Selain itu, penelitian kepustakaan ini digunakan, dengan tujuan untuk menghimpun sumber (data) dari berbagai literatur, menemukan teori, pendapat, prinsip, dan gagasan yang berhubungan dengan kajian Tarekat Syafawi. Setelah data terkumpul, lalu data dipaparkan dengan interpretasi yang tepat sesuai dengan kepentingan sejarahnya. Oleh sebab itu, penelitian ini menggunakan metode deskriptif-analitis untuk mencari data (fakta historis) dan melukiskannnya dengan interpretasi yang tepat, ${ }^{14}$ tentang gerakan politik-keagamaan kaum Tarekat Syafawi di Persia sehingga penelitian ini menggunakan pendekatan sejarah (historical approach). Pendekatan sejarah digunakan dengan maksud untuk memaparkan, menafsirkan, dan menjelaskan data serta mencoba menjawab masalah-masalah yang dihadapi ${ }^{15}$ dengan melalui tiga cara dalam kajian sejarah politik-keagamaan kaum Tarekat Syafawi ini, yakni: kesinambungan dan perubahan (continuity and change), kesejajaran (pararelism), dan perbandingan (comparative). ${ }^{16}$ Selain pendekatan sejarah, penelitian ini juga menggunakan pendekatan sosiologis, sebab sosiologi membahas tentang proses sosial, interaksi sosial, struktur sosial, dinamika sosial, dan perubahan sosial. ${ }^{17}$

Sumber utama kajian pemikiran politik Islam yang dipraktikkan dalam gerakan keagamaan oleh kaum Tarekat Syafawi adalah buku karya Adel Allouche dengan judul The Origins and Develovment of The Ottoman-Safavid Conflict (1500-1555), C.E. Bosworth berjudul The Islamic Dinasties: A Cronological and Geonological Handbook, dan sumber pendukung lainnya yang berkaitan dengan pembahasan mengenai pengalaman sejarah dalam pemikiran politik Islam yang dipraktikkan oleh kaum Tarekat Syafawi di Iran pada abad ke-13 sampai dengan abad ke-18 M.

${ }^{14}$ Moh. Nazir, Metode Penelitian,(Jakarta: Ghalia Indonesia, 1988), h. 63.

${ }^{15}$ Jalaludin Rakhmat, Metode Penelitian Komunikasi, (Bandung: Remaja Rosdakarya, 1991), h. 22.

${ }^{16}$ Kuntowijoyo, Metodologi Sejarah, (Yogyakarta: Tiara Wacana, 1994), h. 12.

${ }^{17}$ Soerjono Soekanto, Sosiologi Suatu Pengantar, (Jakarta: Rajawali, 1982), h.

17. 


\section{B. Peta Sosial Politik-Keagamaan di Iran pada Masa Tarekat Syafawi}

1. Kondisi Sosial-Kultural di Iran

Peradaban adalah sesuatu yang abstrak, yang dapat divisualisasikan hanya dengan melihat manifestasi-manifestasinya. ${ }^{18}$ Menurut Ibnu Khaldun, sebagaimana disinyalir oleh Abdul Jabbar Beg, bahwa peradaban adalah organisasi sosial. Bila organisasi sosial terwujud, maka muncul peradaban. ${ }^{19}$

Teori Ibnu Khaldun dapat dipahami, bahwa peradaban sama halnya dengan negara. Selain itu, teori Ibnu Khaldun dimaksud untuk melihat kondisi sosio-kultur pada periode pertengahan di dunia Islam. Menurut Badri Yatim pada periode pertengahan pembahasan yang paling banyak mendapat tempat adalah percaturan politik di pusat Islam dan peradaban yang di bina oleh dinasti-dinasti yang kebetulan berhasil memegang hegemoni politik. ${ }^{20}$

Pada umumnya wilayah Iran (Persia), pada periode pertengahan dikuasai oleh suku bangsa Turki dan Mongol. Pada periode itu, dunia Islam terbagi dua: bagian Arab dan bagian Persia. Bagian Persia meliputi daerah: Balkan, Turki, Persia, Turkistan, dan India dengan Persia sebagai pusatnya. Namun kekuasaan pada umumnya terletak di tangan dinasti-dinasti suku-suku Turki. ${ }^{21}$ Walaupun di Persia umumnya dikuasai oleh suku-suku Turki, tetapi kebudayaan Persia meningkat di dunia Islam bagian Persia serta mengambil bentuk Internasional sehingga mulai mendesak kebudayaan Arab di dunia Islam. ${ }^{22}$

Kondisi sosial-kultural di Iran itu merupakan peta politikkeagamaan yang selanjutnya dapat digunakan untuk melihat masalah sosial, sekaligus faktor kebudayaan itu dapat digunakan sebagai pendekatan sistem religio-politik di Iran yang dihadapi oleh kaum Tarekat Syafawi, yakni penyebaran ajaran Tarekat Syafawi menggunakan pendekatan kultural di Iran pada masa itu.

${ }^{18}$ M. Abdul Jabbar Beg, Perspektif Peradaban, Pent. Suhendra Yusuf, (Bandung: Pustaka, 1986), h. 30.

${ }^{19} \mathrm{Ibid}$, h. 17-21.

${ }^{20}$ Badri Yatim, Sejarah Peradaban Islam, (Jakarta: Rajawali Press, 1996), Cet. IV, h. 285-6; dan Bosworth, The Islamic...., h. 161.

${ }^{21}$ Nasution, Islam ...., h. 83.

${ }^{22}$ Tbid. 


\section{Kondisi Sosial-Keagamaan di Iran}

Pada periode pertengahan terdapat dua aliran teologi dalam masyarakat muslim, yaitu golongan Syi'ah (dengan sekte-sekte Syi'ah: Zaidiyah, Ismailiyah, Syi'ah Dua belas, dan lain-lain), dan golongan Ahlussunnah (Mu'tazilah, Asy'ariyah, dan Maturidiyah). Selanjutnya yang disebut Ahlussunnah wa al-Jamā'ah (Sunni) adalah Asy'ariyah dan Maturidiyah; sedangkan Mu'tazilah sebagai aliran teologi tersendiri yang bercorak rasional.

Dalam sejarah politik, golongan Sunni (Asy'ariyah) selalu memegang kekuasaan temporal (politik) dalam dunia Islam, seperti dinasti Umayyah dan Abbasiyah. Sebaliknya, golongan Syi'ah termasuk kaum minoritas yang selalu menjadi "korban politik" penguasa Sunni. Sejak peristiwa tahkim, persoalan politik makin tajam dan benar-benar meningkat menjadi persoalan teologi, yang kemudian melahirkan tiga golongan politik yang sarat dengan muatan teologis, yaitu: Khawarij, Syi'ah, dan pendukung Mu'awiyah (Sunni).

Pada periode pertengahan, kondisi Sosio-keagamaan di Iran terdapat dua golongan masyarakat keagamaan yang secara teologispolitis terbagi dua yakni: Syi'ah dan Sunni. Kaum Syi'ah selanjutnya menjadi kelompok mayoritas di bandingkan kelompok Sunni di Iran. Selain itu, masyarakat Iran menganut agama Mazdaisme dan Zoroaster yang pada masa Kerajaan Sasanid dijadikan agama resmi negara. ${ }^{23}$ Pada masa sekarang agama Zoroaster, Yahudi, dan Kristen di Iran masih merupakan kelompok minoritas keagamaan yang diakui di Iran. ${ }^{24}$

Tampaknya peta sosial-kegamaan di Iran dapat diidentifikasikan dalam peta politik-keagamaan di Iran pada masa gerakan Tarekat Syafawi berlangsung di sana. Pada masa Tarekat Syafawi, secara tajam agama Islam dari aliran Sunni dan Syi'ah memberikan pengaruh terhadap penyebaran ajaran Tarekat Syafawi dan cita-cita politik kaum Syafawi di Iran.

Ajaran Syi'ah mengalami perkembangan yang cukup besar, selain berjumpa dengan ajaran tasawuf terutama faham zuhüd aliran

\footnotetext{
${ }^{23}$ Nasir Tamara, Revolusi Islam, (Jakarta: Sinar Harapan,1980), h. 25-26.

${ }^{24}$ Lihat Undang-Undang Dasar Republik Islam Iran, h. 22.
} 
Ja'far Șadiq. Selain itu, para penguasa di Iran, kelompok Assasin di Alamut, Syi'ah Zaidiyah, ${ }^{25}$ Syi'ah Dua belas yang moderat ${ }^{26}$ dianut penguasa Buwaihi yang menguasai Kirman, dan Syirāz di Iran. Itulah beberapa kantong Syi'ah di wilayah Iran pada masa berlangsungnya gerakan keagamaan kaum Tarekat Syafawi.

Sejak abad ke-9 telah turut berkembang di Iran pandangan pribadi ke-Persia-an dalam Islam dan tasawuf yang kedua sulit dipisahkan. Dalam perkembangan tasawuf, Iran telah memberikan jasa yang utama. Seluruh ahli tasawuf mengungkapkan rasa ketasawufannya berupa syair-syair yang berisi rasa tasawuf. Ajaran tasawuf dengan cepatnya bergerak ke Persia. ${ }^{27}$

Ajaran tasawufyang diajarkan kaum Tarekat Syafawi memilik titik temu dengan jaran tasawuf di Iran pada umumnya. Konsep wilāyat, imām dan wirāsat dalam Syi'ah berjumpa dengan konsep qut $b$, silsilah dan $z u h \bar{u} d$, sehingga gerakan keagamaan yang dilakukan kaum Tarekat Syafawi secara doktrinal didorong oleh keyakinan ajaran tarekatnya, lalu mereka berorientasi pada sikap oposisi kaum sufi terhadap penguasa, dan mereka melakukan kritik sosial atas penguasa.

Perkembangan tasawuf atas kritik sosial terhadap penguasa dapatdisalurkan kepada tarekat-tarekatsufi, dengan carabekerjasama antara orang-orang Iran dengan keturunan Imam Ali bin Abu T ālib. ${ }^{28}$ Bahkan, paham Mahdi (Mahdiism) Syi'ah terdapat kesenjangan antara kehidupan rakyat banyak yang telah sarat beban. ${ }^{29}$ Gerakan kaum Syi'ah dalam pemberontakan melawan penguasa Sunni di atas namakan dengan gerakan Mahdi, sebagaimana dilakukan kaum tarekat Syafawiyah ketika memasuki bidang politik. Paham zuhud dijadikan dasar dalam gerakan kritik sosial atas penguasa sekaligus paham zuhud mengilhami perkembangan tasawuf atas kritik sosial

\footnotetext{
${ }^{25}$ Sudirman M. Johan, ”Politik Keagamaan dalam Islam”, Disertasi (Jakarta: Program Pascasarjana IAIN Syarif Hidayatullah, 1994), h. 111.

${ }^{26}$ Bosworth, The Islamic..., h. 96

${ }^{27}$ Aceh, Pengantar Ilmu..., h. 77-78.

${ }^{28} \mathrm{Ibid}$., h. 76-77; dan Annemarie Schimmel, Dimensi-dimensi Mistik dalam Islam, penterjemah Sapardi D. Damono, dkk., (Jakarta: Pustaka Firdaus, 1986), h. 245.

${ }^{29}$ Nouruzzaman Shiddiqi, Jeram-jeram Peradaban Muslim, Cet. ke-1, (Yogyakarta: Pustaka Pelajar, 1996), h. 143-144.
} 
terhadap penguasa yang tidak menegakkan keadilan. Tampaknya, paham zuhud berhubungan secara simbolis dengan paham Mahdi sebagai perkembangan ajaran imāmah dalam Syi'ah Dua belas di Iran di mana doktrin imāmah itu sangat mendorong cita-cita sistem religio-politik bagi kaum Syi'ah Dua belas termasuk kaum tarekat Syafawiyah yang merubah doktrin teologisnya dari Sunni ke Syi'ah Dua belas.

\section{Kondisi Sosial-Politik di Iran}

Sejak munculnya Tarekat Syafawi di Iran terdapat beberapa suku yang berkuasa di beberapa wilayah Iran seperti: suku Turki, suku Kurdi, bangsa Mongol, termasuk bangsa dari keturunan suku Arab akibat dari pengaruh disintegrasi politik pada abad pertengahan di dunia Islam.

Munculnya berbagai suku atau bangsa yang kemudian mereka menguasai wilayah di masing-masing kekuasaan mereka merupakan pengaruh dari disintregasi di bidang politik yang terjadi di dunia Islam pada periode pertengahan. Disintegrasi dalam lapangan politik di pusat pemerintahan Islam, di Baghdad pada masa Daulah Abbasiyah, pengaruhnya pun dapat dirasakan di daerah-daerah lain yang masuk ke dalam wilayah kekuasaan umat Islam, termasuk di Iran. Persaingan sesama bangsa Turki di Persia yaitu al-Qiyunlu dan Qara Qiyunlu. Di sisi lain al-Qiyunlu bermusuhan dengan Turki Usmani, serta Qara Qiyunlu bermusuhan dengan Timur Lenk dari bangsa Mongol. ${ }^{30}$

Secara politik, ungkap C.E. Bosworth, bahwa munculnya Qara Qiyunlu berarti menandakan berakhirnya pemerintahan Timur Lenk di Iran (Persia Barat) karena kegagalan Dinasti Timuriyah mempertahankan diri di Persia Barat. Namun secara etnis, pemusatan orang-orang Turki mempercepat proses politisasi yang membuat Azerbaijan dikuasai oleh bangsa dan bahasa Turki. Bahkan, Qara Qiyunlu yang menganut Syi'ah menyebabkan dominasi suku bangsa Turki di Asia Barat pada masa itu seperti ditunjukkan dengan tampilnya kaum Syafawi yang juga ditelusuri berasal dari keturunan bangsa Turki di Persia. ${ }^{31}$

${ }^{30}$ Bosworth, The Islamic..., h. 168.

${ }^{31}$ Ibid., h. 169. 
Kondisi sosial-politik di Iran yang demikian, di antara yang mendorong kaum Tarekat Syafawi merubah gerakan Tarekat Syafawi dari bidang keagamaan ke bidang politik yang kemudian menyatu menjadi gerakan politik-keagamaan. Gerakan kaum Tarekat Syafawi di bidang keagamaan yang kemudian beralih ke gerakan politik di Iran dapat dijelaskan berikut ini untuk melihat perkembangan sistem religio-politik kaum Tarekat Syafawi di Iran.

\section{Gerakan Politik-Keagamaan Kaum Tarekat Syafawi di Iran}

1. Gerakan keagamaan Kaum Tarekat Syafawi di Iran

Gerakan keagamaan di bidang tarekat merupakan perkembangan dari ajaran tasawuf. Tasawuf menurut al-Qusyairi merupakan suatu ilmu pengetahuan dan sebagai ilmu pengetahuan tasawuf mempelajari cara dan jalan bagaimana seorang Islam dapat berada sedekat mungkin dengan Allah swt. ${ }^{32}$

Pengertian tasawuf demikian mengandung tujuan, cara dan jalan untuk mencapai suatu tujuan bagi seorang hamba (makhluk) yang ingin berhubungan dan dekat dengan Allah swt. (al-Khālik). Menurut Harun Nasution tasawuf mempunyai tujuan memperoleh hubungan langsung dan disadari dengan Tuhan, sehingga disadari benar, bahwa seorang berada di hadirat Allah swt, bahkan kesadaran berada dekat dengan Tuhan itu dapat mengambil bentuk Ittihād, bersatu dengan Tuhan. ${ }^{33}$ Untuk berada dekat dengan Tuhan, Seorang sufi harus menempuh jalan panjang yang dijalankan melalui tingkatan-tingkatan (maqāmat).

Tahapan-tahapan itu menunjukkan tahapan pada tujuan tasawuf. Tujuan tasawuf itu sangat dipengaruhi oleh: tasawauf akhlaki, tasawuf amali, dan tasawuffalsafi. ${ }^{34}$ Beberapa tahapan dalam tujuan tasawuf itu ditentukan sesuai dengan kesanggupan melewati tangga-tangga (maqāmat) untuk lebih dekat bahkan mengadakan persatuan dengan Tuhan. Beberapa tahapan itu merupakan formulasi ilmu tasawuf dari pertumbuhan dan perkembangannya.

\footnotetext{
${ }^{32} \mathrm{Abu}$ al-Qasim al-Qusyairi, Al-Risalah al-Qusyairiyyah fi 'Tlm al-Tasawwuf, editor: Moh. Ali Shahib, (Mesir: Al-Azhar, 1996), h. 126.

${ }^{33}$ Harun Nasution, Falsafat dan Mistisisme dalam Islam, Cet. VI, (Jakarta: Bulan Bintang,1989), h. 56.

${ }^{34}$ A. Zuhdi Anwar, Ilmu Tasawuf Sebuah Pengantar, (Jakarta: Fak. Ushuluddin IAIN Jakarta,1985), h. 9.
} 
Masa awal kegiatan tasawuf mengambil bentuk kegiatan zuhud, yang bersumber dari al-Qur'an dan Hadis Nabi, atau perbuatan Nabi Muhammad saw..$^{35}$ dan seterusnya diikuti oleh para sahabat, lalu timbul istilah "nusak, zuhūd, bakkaun, dan kussas" ${ }^{36}$ Dalam perkembangan selanjutnya, muncul aliran zuhud pada abad ke-7 dan 8. Aliran zuhud lahir sebagai reaksi terhadap hidup mewah dari kholifah, keluarga dan pembesar-pembesar negara sebagai akbat dari kekayaan yang diperoleh setelah Islam meluas ke Mesir, Syiria, Mesopotamia, dan Persia. ${ }^{37}$

Praktik zuhud bertujuan selain untuk membersihkan jiwa dan dekat dengan Tuhan, juga menghindari praktik-praktik kemewahan dan kemegahan sebagaimana dilakukan oleh dinasti Umayyah (661750) dan dinasti Abbasiyah (750-1258)..$^{38}$ Tampaknya, ajaran zuhud selain bemuatan ajaran sufistik juga sangat sarat dengan muatan politik. Hal demikian dapat ditunjukkan dalam bukti sejarah praktik politik sistem daulah, yakni pertentangan politik antara Bani Umayyah dengan kaum Syi'ah misalnya, makin mendorong timbulnya praktik zuhud yang membawa kepada kebencian dan beroposisi terhadap penguasa Bani Umayyah dan Bani Abbas.

Pada abad ke-7 dan 8 itu muncul pula tokoh-tokoh zuhud di Bashrah, Kufah, Persia dan lain-lain. Aliran zuhud Kuffah berpembawaan idealis dan tradisionalis, dan aliran zuhud Bașrah, termasuk di Persia, berpembawaan realistis dan kritis. Zuhud di Persia dikembangkan oleh Ibrahim bin Adham (w.782) dan Syaqiq alBalkh (w.810). Di Madinah aliran zuhud ketokohannya diwakili oleh Ja'far al-Ṣadiq (w.810). ${ }^{39}$

Mulai abad ke-9, aliran zuhud berkembang menjadi aliran tasawuf, lalu timbul spesialisasi dalam tasawuf yang isinya soal jiwa, akhlak dan ketuhanan (metafisik). ${ }^{40}$ Pertanggungjawaban ilmu akhlak lebih banyak kepada masyarakat. Isi tasawuf pada abad

\footnotetext{
${ }^{35}$ Hamka, Tasawuf..., h. 60; dan Reynold A. Nicholson, The Idea of Personality in Sufism, (New Delhi: Idarat-i Adabiyat-i,1976), h.3.

${ }^{36}$ H.A.R. Gibb, Shorther Encyclopedia of Islam, (Leiden: Luzac and Co.Ltd., tt.,h. 580.

${ }^{37}$ Ibid., h. 64

${ }^{38}$ Hamka, Tasawuf..., h. 56-57.

${ }^{39}$ A. Zuhdi Anwar, Ilmu Tasawwuf ..., h. 18-22.

${ }^{40}$ Hamka, Tasawuf, ..., h. 96.
} 
ke-9 dan 10 isi utamanya tentang hubungan cinta dengan Tuhan, sehingga perkembangan tasawuf cukup pesat dengan mengambil corak tasawuf falsafi. ${ }^{41}$ Di Persia tasawuf mengambil kedudukan lebih tinggi dalam rangka pembentukan kekuatan moral. Pada abad ini tasawuf juga terkenal di Kuffah dan Bashrah. ${ }^{42}$

Di Persia (Iran), pembentukan kekuatan moral itu berkaitan dengan kondisi kota Bagdad, yaitu kekuasaan Bani Abbas tenggelam dalam kemewahan dan tekanan-tekanan Bani Abbas terhadap kaum Syi'ah di Kuffah. Ali Ibn Abi Țalib, Salman al-Farisi, Abi Zar dianggap sebagai unsur menentukan dalam sejarah tasawuf Persia dan pemikiran Syi'ah. ${ }^{43}$ Kota Kuffah adalah kantong Syi'ah dan tempat tinggal Abū Hāsyim, sufi pertama. Abd al-Wāḥid Ibn Zaid, pengikut Hasan al-Bașri, mendirikan pemukiman bagi orang-orang yang suka bertapa di Abadan, di Teluk Persia. ${ }^{44}$ Sejak abad ke-9, kaum Syi'ah diilhami oleh pemikiran mistik Imam Ja'far al-Ṣādiq, ${ }^{45}$ dan lahirnya faham hulul di Persia oleh al-Ḥallaj (858-922), sehingga tasawuf mengalami serangan dan tuduhan dari penguasa Bani Abbas bahwa al-Ḥallaj mempunyai hubungan dengan Qarāmitah yang menentang pemerintahan Bani Abbas mulai abad ke-10 dan $11 .^{46}$

Abad ke-10 merupakan masa organisasi dan konsolidasi tasawuf. Banyak sufi merasa hubungan akrab dengan keluarga Nabi saw. tanpa mempercayai doktrin Syi'ah. Namun dalam abad ke-9 dan 10, pemikiran Syi'ah berhubungan akrab dengan ajaran tasawuf, ${ }^{47}$ sebagai akibat peranan penting tafsir al-Qur'an Imam Ja'far yang membentuk beberapa gugus dan persaudaraan sufi di Ardabil, yaitu kaum Tarekat Syafawi yang dipelopori oleh Șafi al-Din dalam perkembangan selanjutnya sejak abad ke-13 hingga 15, Tarekat sufi kaum Syafawi ini menjadi propaganda Syi'ah di Persia. ${ }^{48}$

Pada abad ke-11, aturan dasar pendidikan mistik (sufistik) diperinci secara jelas, sehingga berangsur-angsur ajaran kaum sufi

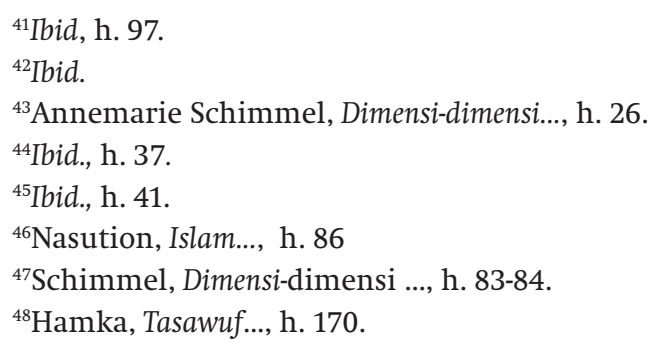


mulai menarik perhatian kalangan masyarakat luas. Selanjutnya pada abad ke-12, kegiatan sosial kelompok sufi yang sedang berkembang itu, tampak sebuah sikap baru, yakni terjadi perubahan dari kelompok elit menjadi gerakan massa yang menyebarkan ajaran sufistik keseluruh tingkatan masyarakat. ${ }^{49}$ Pengaruhnya luar biasa, di antaranya: hubungan kelompok sufi dengan kaum penguasa sering dingin untuk menjaga kesucian jiwa mereka dan seorang darwis dijadikan penyambung lidah bagi kritik sosial akibat penyakit sosial dan keadaan negara yang rusak. ${ }^{50}$

Pada abad ke-11, puncak kemajuan tarekat sufi berubah menjadi gerakan tarekat sufi, bahkan menjadi suatu kritik sosial yang berdampak pada kecendrungan politik (kekuasaan). Dengan demikian, perkembangan tasawuf pada abad ini memberikan perkembangan bagi kaum Syi'ah yang ingin mengembalikan kekuasaan kepada keturunan Imam 'Ali Ibn Abỉ Tạalib, yakni alMahdi, yang akan memimpin dunia dengan penuh keadilan. Hal ini didukung oleh makin dekatnya ajaran tasawuf dengan ajaran Syi'ah, terutama di Persia. Banyak kaum tarekat menyatakan sebagai Quṭb zamannya dan banyak di antara mereka mengambil peranan sebagai Mahdi. Penghormatan yang di tujukan kepada Imām dan Quṭb itu umum dikenal oleh ajaran tasawuf dan doktrin Syi'ah. Dalam teosofi Iran, Quṭb dianggap sebagai tempat kedudukan Sarosh (malaikat Zoroaster yang patuh, memberi ilham dan kebangkitan). ${ }^{51}$

Pada abad ke-12 dan 13, ajaran tarekat sufi makin berkembang menjadi corak tasawuf falsafi (ketuhanan) dalam suatu aliran tarekat seperti ajaran Hikmah al-Isyrāq oleh Suhrawardi al-Maqtūl (w.1191). Pada abad ke-13, ajaran-ajaran sufi mengambil bentuk tarekat dan mutunya mulai menurun. Bahkan, sejak abad ke-14 tidak terdengar lagi perkembangan pemikiran yang baru dalam tasawuf,, ${ }^{52}$ mungkin salah satu alasannya tasawuf dalam bentuk tarekat lebih bergerak di bidang politik, dan seterusnya bertujuan politik pada kekuasaan temporal di Iran.

\footnotetext{
${ }^{49}$ Aceh, Pengantar Пmu..., h. 236.

${ }^{50}$ Schimmel, Dimensi-dimensi..., h. 114-115.

${ }^{51}$ Ibid., h. 238-239.

${ }^{52}$ Nasution, Islam Ditinjau..., h. 83.
} 


\section{Gerakan Politik Kaum Tarekat Syafawi di Iran}

Situasi politik di Iran mendorong gerakan Tarekat Syafawi mengubah bentuknya dari keagamaan memasuki gerakan politik. Kecenderungan tarekatini memasuki bidang politikmendapatwujud nyata pada masa kepemimipinan Junaid (1447-1460). Ia memperluas gerakan tarekatnya pada kegiatan keagamaan sekaligus kegiatan politik. Sejak ia memperluas dan mempertahankan kelompok tarekatnya, ia bersama dengan para pengikutnya mempunyai visi, konsepsi, dan misi reaksionar (revolusioner) pada tujuan kekuasaan (negara).

Ambisi kekuasaan politik bagi Junaid, ia lakukan dalam suatu gerakan politik melalui lembaga tarekat yang berfungsi sebagai lembaga politik-keagamaan kaum Tarekat Syafawi yang memperlihatkan suatu corakgerakan darigerakan keagamaan kepada gerakan politik sehingga tercerminlah gerakan politik-keagamaan kaum Tarekat Syafawi di Iran. Perubahan demikian menunjukkan perubahan kepemimpinan spiritual memasuki pada kepemimpinan temporal yakni kekuasaan politik praktis dan kekuasaan militer bagi Kaum Syafawi di Iran yang dipelopori oleh Junaid. ${ }^{53}$

Ada beberapa faktor yang menyebabkan Junaid dan pengikutnya melakukan perubahan-perubahan sosial dalam politikkeagamaan di Iran, baik disebabkan oleh faktor internal maupun eksternal yang mendorong pimpinan Tarekat Syafawi ini berambisi mewujudkan cita-cita politiknya untuk merebut kekuasaan dari tangan penguasa di Iran pada masa itu.

Faktor internalnya, ialah berasal dari dalam kelompok Syafawi (in sider) yang didasari oleh ajaran sufistik yang bercorak religio-politik atas dorongan doktrin imämah yang dianut oleh kaum Syi'ah Imāmiah (Syi'ah Dua belas) di Iran. Faktor internal lainnya, ialah kepentingan sosial kelompoknya (social interest) kaum Tarekat Syafawi sesuai dengan tujuan tarekat dan cita-cita politiknya. Untuk itu, langkah pertama ialah Junaid menyakinkan para pengikutnya agar mereka memberikan kesetiaan kepadanya.

Selanjutnya, Junaid melakukan beberapa taktik dan langkah strategis politiknya, untuk mengelabui para pengikutnya dan

\footnotetext{
${ }^{53}$ Allouche, The Origins..., h. 103; dan Julian Baldick, Mistycal Islam.., h. 110.
} 
pendukungnya sekaligus menutup-nutupi kelemahan keturunan nenek moyangnya yang pernah menjadi pemimpin gerakan Tarekat Syafawi serta untuk mempermudah tujuan bagi ambisi politiknya dan tujuan mewujudkan kekuasaan di Iran.

Beberapa strategi dan taktik yang ditempuh untuk Junaid dalam gerakan politik di Iran, antara lain: Pertama, Junaid tetap berusaha mewujudkan ambisi politiknya dengan jalan merubah gerakan keagamaan menjadi gerakan politik dan menyusun kekuatan militernya, mengorganisir pasukannya, dan meningkatkan birokrasi dan administrasi kemiliterannya dalam tubuh Qizilbaṣ. Pasukan Qizilbas adalah pasukan militer khusus (baret merah dengan simbol 12) yang terlatih dan merupakan garda terdepan militer kaum Tarekat Syafawi di Iran yang setia kepada pemimpin politik kaum Tarekat Syafawi dengan dilegitimasi doktrin imāmah dan ajaran tarekat yang diyakininya dalam mewujudkan cita-cita politik dan ambisi kekuasaan Kaum Syafawi di Iran. ${ }^{54}$

Kedua, Junaid bekerjasama dengan para pengikut dan pendukung Tarekat Syafawi sehingga mereka menampakkan sikap militannya yang didasari oleh doktrin Syi'ah Dua belas, yang kemudian Kaum Syafawi beralih keyakinan dari doktrin Sunni pada masa awal gerakan tarekat ini, dan pada masa Junaid ini lebih tampak jelas ke permukaan masyrakat menjadi penganut Syi'ah Dua belas yang mendorong pasukan Junaid bergerak di bidang politik kekuasaan di Iran.

Ketiga, di pihak lain, Junaid bekerjasama dengan penguasa Ardabil saat itu. Ia memanfaatkan kondisi politik yang sedang mengalami kekacauan dan peperangan. Hal demikian menimbulkan Junaid dan pasukannya yang menganut Syi'ah Dua belas mendapat perlawanan dari penguasa Syah Ruh (Timuriyah) sebagai pengikut Sunni yang sedang menghadapi perlawanan dari pihak al-Qiyunlu pimpinan amir Uzun Hasan (1444-1453) penganut Sunni di Diyarbakr. ${ }^{55}$

Pada saat itu pula, di Anatolia sedang terjadi perlawanan antara Kerajaan Turki Usmani, pimpinan Sultan Murad II (1421-

\footnotetext{
${ }^{54}$ Allouche, The Origins.., h. 104-105 dan Bosworth, The Islamic..., h. 171.

${ }^{55}$ Ibid., h. 105.
} 
1451) dengan Dinasti Timuriyah yang dipimpin Syah Ruh (14051447). Kondisi politik-keagamaan yang terjadi di Persia dimerupakan faktor eksternal yang memicu Junaid melakukan perubahan politik di Persia melalui gerakan Tarekat Syafawi bersama pasukan Qizilbaṣ. ${ }^{56}$

Dengan demikian, gerakan Tarekat Syafawi sudah terlibat langsung dalam kegiatan politik dan keagamaan disatukan untuk mewujudkan cita-cita dan tujuan politiknya. Dalam rangka memantapkan ide barunya yang bersifat religio-politik, Junaid pertama-tama meyakinkan kepada para pengikut dan pendukungnya, bahwa para pemimpin Tarekat Syafawi, termasuk Junaid, mengklaim keturunan dari Imam 'Ali bin Abỉ Țālib. Ternyata ide tersebut yang disampaikan oleh Junaid kepada pengikutnya bermaksud untuk menyebarkan atau mepropagandakan risalah dakwah (misi dakwah) berupa ide-ide Syi'ah serta menampakkan ambisi dan kekuatan politiknya. ${ }^{57}$

Dalam menyebarkan ide-ide Syi'ah itu, Junaid bergerak ke daerah Konya; namun dari Konya ia melarikan diri ke Sisilia karena ajaran Syi'ah yang dipropagandakan itu tidak menguntungkan pemerintahan dan para mutakallim di Konya. Selanjutnya, Junaid berdakwah ke Killis dan Jabal Musa, sebuah desa di Antiokia yang banyak dipengaruhi oleh gerakan Hurufi ${ }^{58}$ karena di dua desa itu Junaid mengalami nasib seperti di Konya, lalu ia mengirimkan surat kepada Uzun Hasan, dan selanjutnya ia melakukan perjalanan ekspedisinya ke Syiria Utara dan di Syiria ini Junaid bertambah pengikutnya. $^{59}$

Dari Syiria Junaid menuju ke Diyarbakr. Wilayah Diyarbakr pada saat itu merupakan wilayah kekuasaan al-Qiyunlu, pimpinan Uzun Hasan yang ketika itu ia menguasai sebagian besar wilayah Persia. Sesampai di Diyarbakr, Junaid diterima oleh Uzun Hasan dan ia tinggal di Istana Uzun Hasan. Uzun Hasan adalah keturunan bangsa Turki yang menganut Sunni. Namun hubungan keduanya cukup

${ }^{56}$ Bosworth, The Islamic..., h. 171-2.

${ }^{57}$ Adel Allouche, The Origins ..., h. 100-1; ia mengutip sumber dari Asikpasazade, Tevarih, ha1. 264-9 mengenai ajaran Syi'ah yang dipropagandakan oleh Junaid di daerah Konya untuk tujuan politik.

${ }^{58}$ Annemarie, Dimensi-dimensi..., h. 352.

${ }^{59}$ Allouche, The Origin..., h. 101. 
akrab, familier dan harmonis, sehingga Junaid dikawinkan dengan Martha yaitu anak perempuan dari Calo Joanes. Catatan perkawinan itu menjadikan hubungan (kerjasama) Junaid dengan Uzun Hasan makin akrab sehingga al-Qiyunlu (penganut Sunni) pimpinan Uzun Hasan memenangkan peperangan melawan Qara Qiyunlu (penganut Syi'ah) di Diyarbakr, karena pasukan Uzun Hasan diperkuat oleh Qizilbaș yang dipimpinan oleh Junaid. Hasil pernikahan Junaid dengan Calo Joanes lahirlah anak yang diberi nama Haidar. ${ }^{60}$

Pada tahn 1459, Junaid kembali ke Ardabil, dan ia mencoba merebut kekuasaan dari tangan Qara Qiyunlu, tetapi usaha Junaid itu gagal. Pada tahun 1460, Junaid mencoba lagi merebut Sircassia yang dikuasai pasukan Syirwan Syah, tetapi Junaid gagal dan bahkan ia mati terbunuh di lembah Karasau. ${ }^{61}$ Tarekat Syafawi selama kepemimpinan Junaid telah menunjukkan kekuatan politiknya yang begitu kuat semasa hidupnya kepada para pengikutnya yang kebanyakan berasal dari bangsa Turkoman yang menganut paham Syi'ah Dua belas. Kekuatan politik Junaid posisinya semakin kokoh setelah ia menikah dengan saudara perempuan dari Uzun Hasan, bernama Calo Jeanes.

Kekuatan politikJunaidsecaralangsungmampumenghimpun kekuatan bagi pemimpin kaum Syafawi dalam kehidupan politik masyarakat Iran. Junaid merupakan pemimpin pertama yang membentuk citra baru solidaritas sosial dan kebangsaan Persia (Iran) berdasarkan komitmen keagamaan, etnis dan moralitas. Usahanya selama masa kepemimpinannya mampu melakukan penyebaran ideide Syi'ah bagi para murid, pengikut dan bahkan pendukungnya, sekaligus menunjukkan kekuatan politik dan militernya dengan ajaran-ajaran Syi'ah kepada para pengikut dan pendukung dari suku Turkoman di Anatolia dan Syiria Utara. ${ }^{62}$

Haidar (1460-1494) adalah anak dari Junaid yang meneruskan perjuangan ayahnya. Ketika Junaid wafat, Haidar masih kecil, sehingga ia dibawah asuhan dan perlindungan Uzun Hasan, dan kepemimpinan tarekat Syafawi baru diserahkan kepada Haidar

${ }^{60}$ Ibid., h. 112.

${ }^{61}$ P.M. Holt, et.al. (ed), The Cambridge History of Islam, (London: Cambridge University Press, 1970), Vol. I.A., h. 396.

${ }^{62}$ Allouche, The Origin ..., h. 114. 
tahun 1470. Hubungan Haidar dengan Uzun Hasan semakin erat, setelah Haidar menikah dengan putri Uzun Hasan, bernama Despina Khatun. Akan tetapi, dalam buku Habỉb al-Siyār karya Khawandamir dan Silsilat al-Nasab karya Zahidi dinyatakan bahwa Uzun Hasan menikahkan Haidar dengan Halimah Begum -lebih dikenal dengan nama Alamsyah. ${ }^{63}$ Haidar juga mempunyai ambisi politik yang lebih kuat dari ayahnya, Junaid.

Ambisi politik Haidar dalam gerakan Tarekat Syafawi didorong oleh beberapa faktor kepentingan dan ambisi politik Kaum Syafawi, sehingga Haidar dan pasukannya melakukan langkahlangkah politik yang strategis, antara lain: Pertama, Haidar mulai mengorganisir para pengikutnya menurut garis-garis persaudaraan ksatria Eropa. Kedua, dalam usaha meningkatkan militansi kepada pengikutnya, Haidar membuat perlambang baru bagi kaum Tarekat Syafawi bernama Qizilbaș yang berasal dari suku Turki menunjukkan kesetiaan dan kepatuhan kepada Haidar. Ketiga, Haidar sebagai pemimpin Tarekat Syafawi melembagakan dan mencirikan ajaran Syi'ah Dua belas dengan dikawal oleh pasukan baret merah Qizilbas sebagai lambang semangat gerakan politik kaum Tarekat Syafawi. ${ }^{64}$ Keempat, Haidar membuat heterodoksi Syi'ah dalam bentuknya yang ekstrim (Syi'ah al-Gulāt), karena Haidar memandang dirinya suci dan memiliki sifat ketuhanan (ilāhiyah), dan pemimpin yang suci (ma'ș $\bar{u} m)$.

Menurut keyakinan Syi'ah Dua belas, doktrin imāmah sebagai bagian ajaran pokok Syi'ah Dua belas. Mereka meyakini bahwa setiap umat yang hidup di muka bumi harus dipimpin oleh seorang imam. Imam adalah pemimpin setengah ilahi yang kharismatik, sebagai perantara manusia dan Tuhan. Imam menurut ajaran Syi'ah Dua belas selain mempunyai kemampuan wașāyah (pemegang otorisasi wasiat agama) dan walāyah (pemegang otiorisasi kekuasaan temporal). Selain itu, imam juga mempuyai sifat 'ișmah, nubuwwah, dan 'adālah. Namun karena para pemimpin Tarekat Syafawi bukan termasuk keturunan Imam Ali Ibn Abi Ṭālib, berarti mereka pun tidak memiliki kemampuan dan sifat-sifat

${ }^{63}$ Ibid., h. 117.

${ }^{64}$ Ibid., h. 118. 
sebagaimana para imam (12 imam Syi'ah); dan oleh karenya mereka merasa dan meyakini sebagai "pengganti Imam Gaib bernama al-Mahdi al-Muntazar" (nuwāb al-imām), maka pemimpin Tarekat Syafawi termasuk Haidar mengklaim dirinya sebagai nuwāb al-imām (wakil Imam) dan menobatkan dirinya di tengah pengikutnya sebagai pemimpin setengah ilahi. ${ }^{65}$

Dengan demikian dapat dipahami, sejak kepemimpinan Haidar inilah, gerakan Tarekat Syafawi sebagai gerakan Mahdiyah dengan tujuan supaya masyarakat tercipta suasana keadilan, keselamatan, dan kebenaran hidup sesuai yang dikonsepsikan oleh Haidar. Untuk mewujudkan keadilan ini, Haidar melakukan gerakan politik-keagamaan untuk mewujudkan cita-cita dan ambisi politiknya dalam perjuangannya dengan mengatas namakan gerakan Mahdiyah. ${ }^{66}$

Paham Mahdiyah berkaitan dengan keadilan yang mengandung dimensi teologis (doktrin imāmah) sekaligus dimensi politis (hak imāmah, harus dipegang oleh imām/wakil imām). Untuk itu, Haidar dan pengikutnya menuntut kematian ayahnya, Junaid, yang terbunuh di tangan penguasa Syirwan yang dipandang oleh Haidar, dipandang tidak adil, berbuat zalim dan kejam. Namun ketika Haidar dan pasukan Qizilbaș melakukan serangan untuk membalas kematian ayahnya, Haidar pun mati terbunuh di Circassia, sebab alQiyunlu mengirimkan bantuan militernya kepada Syirwan Syah.

Haidar memiliki tiga putra, yaitu: Ali, Ibrahim, dan Ismail. Ali ibn Haidar (1494-1501) adalah penerus kepemimpinan ayahnya bernama Haidar. Ali didesak juga oleh bala tentaranya untuk menuntut kematian ayahnya terutama kepada pihak al-Qiyunlu, tetapi Ya'qub, anak Uzun Hasan, dapat menagkap Ali dan Ali dimasukkan ke penjara bersama Ibrahim dan Ismail serta ibunya selama empat tahun (1489-1493) di Fars. Lalu mereka dibebaskan oleh Rustam, putra mahkota al-Qiyunlu, dengan syarat mereka membantu Rustam memerangi saudara sepupunya. Saudaranya itu dikalahkan oleh pengikut ayahnya di Ardabil. ${ }^{67}$ Sepeninggalan Ali ibn Haidar,

${ }^{65}$ Ibid., h. 118-9.

${ }^{66}$ G.H. Jansen, Islam Militan, pentj. A. Mazhar, (Bandung: Pustaka, 1983), h. 26.

${ }^{67}$ Holt, (et.al.), The Cambridge...., h. 397. 
kepemimpinan gerakan politik-keagamaan kaum Tarekat Syafawi diteruskan oleh Ismail ibn Haidar.

Pada masa kepemimpinan Ismail ibn Haidar (1501-1524), gerakan politik-keagamaan kaum Tarekat Syafawi lebih ditujukan pada gerakan sosial-politik dengan tujuan merebut kekuasaan politik dan mendirikan negara berbasis doktrin Syi'ah Dua belas sebagai mazhab negara di Iran. ${ }^{68}$

Ismail adalah sosok seorang pemuda yang sangat ambisius untuk menguasai politik dan berkuasa di Iran berdasarkan doktrin Syi'ah Dua belas. Ia menghimpun kekuatan politik yang didasarkan pada doktrin Syi'ah dan berkonsolidasi dengan pasukan Qizilbaṣ. ${ }^{69}$

Beberapa langkah strategis yang dilakukan oleh Ismail ibn Haidar dalam mengkonsolidasikan pasukan Qizilbaṣ untuk meningkatkan gerakan politik-keagamaan di Iran, antara lain: Pertama, Ismail ibn Haidar menyatakan dirinya keturunan Imam Musa al-Kazim dan Ismail pun menyatakan dirinya sebagai wakil imam gaib, al-Mahdi. ${ }^{70}$ Kedua, Ismail ibn Haidar menyatakan dirinya memiliki sifat ketuhanan (ilāhiyāt) serta meyakinkan dirinya kepada pengikutnya bahwa dirinya titisan Tuhan yang berwujud pada dirinya (reinkarnasi) atau tanāsukh. ${ }^{71}$ Faham ilāhiyāt dan tanāsukh yang dianut oleh Ismail bertujuan untuk meyakinkan kesetiaan pasukan Qizilbaș atas kepemimpinannya dalam mewujudkan kekuasan politik. Ketiga, Ismail ibn Haidar mengharuskan kepada setiap pasukan Qizilbas untuk menyatakan sumpah janji setia (bai'at) mereka kepada Ismail ibn Haidar dengan mengucapkan: Là ilāha illa Allāh wa Ismā'ill wali Allāh (tiada tuhan kecuali Allah dan Ismail adalah wali Allah)..$^{72}$ Pada masa kepemimpinan Ismail ibn Haidar, gerakan politik-keagamaan bagi kaum Tarekat Syafawi yang semula berpusat di Ardabil dipindahkan

\section{${ }^{68}$ Ibid., h. 398.}

${ }^{69}$ A.K.S. Lambton, State and Government in Medieval Islam, (Oxford: Oxford University Press, 1991), h. 264.

${ }^{70}$ Moojan Momen, An Introduction to Shi'i Islam, (New Haven and London: Yale University Press, 1985), h. 105.

${ }^{71}$ Ira M. Lapidus, A History of Islamic Society, (Cambridge: Cambridge University Press, 1998), h. 285.

${ }^{72}$ Allouche, The Origin..., h. 130; Holt, (et.al.), The Cambridge. ..., h..396; dan Syed Mahmudunnasir, Islam: Its Concepts and Hitory, (New Delhi: Kitab Bhavan, 1981), h. 313. 
ke Gilan. Di wilayah Gilan ini, Ismail terus melakukan konsolidasi dengan para pengikutnya di Azerbeyjan, Syiria, dan Anatolia, untuk mempersiapkan dan menghimpun kekuatan pasukan Qizilbas yang berasal dari kumpulan suku Turki, untuk menyerbu dan mengalahkan al-Qiyunlu di Syurūr, dekat Nakhevivan. ${ }^{73}$

Kemudian pasukanQizilbașterusmemasukidanmenak-lukkan Tabriz, ibu kota al-Qiyunlu, dan akhirnya Ismail ibn Haidar bersama pasukan Qizilbaș, pada hari Jum'at tahun 1501 M memproklamasikan dirinya sebagai penguasa politik pertama dengan gelar raja (syah) sekaligus pemimpin Tarekat Syafawi dengan gelar syaikh pertama yang berhasil mendirikan Dinasti Syafawi. ${ }^{74}$

Ismail ibn Haidar dalam proklamasi berdirinya Dinasti Syafawi tahun $1501 \mathrm{M}$, ia juga memutuskan ajaran Syi'ah Dua belas (Syi'ah Isna 'Asyariyah) diberlakukan sebagai agama resmi negara Iran. ${ }^{75}$ Syed Mahmudunnasir mengatakan dengan kalimat "Syi'ah menjadi madzhab resmi negara" di Iran dibawa oleh kaum Syafawi dalam gerakan politik-keagamaan melalui ajaran tarekat yang berubah ke doktrin Syi'ah. ${ }^{76}$

Dengan demikian, Ismail ibn Haidar adalah pemimpin Tarekat Syafawi yang menjadi syaikh dan syah pertama kali pada Dinasti Syafawi bagi kaum Syi'ah Dua belas di Iran sejak awal abad ke-16 M hingga abad ke-18 M.

\section{Penutup}

Untuk menutup seluruh uraian ini perlu disimpulkan bahwa pemikiran politik dalam Islam itu lahir selain dilatarbelakangi oleh sebab-sebab yang terkandung dalam ajaran teologis, juga ajaran tasawuf ketika berkembang di tengah masyarakat yang berubah menjadi gerakan tarekat terutama digali dari pemahaman ajaran zuhud dan dorongan kondisi sosial politik-keagamaan di dunia Islam, khususnya di Iran yang dilakukan oleh kaum Tarekat Syafawi.

Praktik politik-keagamaan yang dilakukan oleh kaum

${ }^{73}$ Allouche, The Origine..., h. 131.

${ }^{74}$ Holt, (et.al.), The Cambridge..., h. 397.

${ }^{75}$ Allouche, The Origin ..., h. 131-2 dan Syed Amir Ali, The Spirit of Islam, (Ballimaram, Delhi: Idārah-i Adabiyat-i Delhi, 1978), h. 134.

${ }^{76}$ Syed Mahmudunnasir, Islam..., h. 313. 
Tarekat Syafawi di Iran (Persia) pada abad ke-13 sampai dengan abad ke-18 gerakan keagamaan berubah menjadi gerakan politik yang melahirkan gerakan politik-keagamaan yang dilandasi paham Mahdiisme dan doktrin imāmah semakin memperkuat posisi Kaum Syafawi dengan lahirnya pasukan militer Qizilbaș, memperluas pengaruh gerakan mereka, mampu menjalin kerjasama dengan pihak penguasa di Iran seperti al-Qiyunlu dan Qara Qiyunlu dengan taktik dan strategi politiknya. Dengan taktik dan strategi politikkeagamaan yang dilakukan di Iran, maka kaum Tarekat Syafawi berhasil mendirikan Dinasti Safawi dengan menjadikan doktrin Syi'ah Dua belas sebagai mazhab resmi negara di Iran guna melembagakan doktrin Syi'ah sekaligus mewujudkan sistem religiopolitik kaum Syi'ah Dua belas yang berdasarkan doktrin imāmah.

Oleh karena itu, saran-saran dari penulis, bahwa kaum pengamal tarekat seperti Tarekat Syafawi agar mampu menjadikan ajaran tarekatnya sebagai kekuatan sosial untuk membangun tata sosial-politik yang didasari nilai-nilai keagamaan yang diajarkan dalam tarekat tersebut, dan tentunya tata sosial-keagamaan agar didukung oleh praktik politik yang Islami untuk meraih kebahagiaan dan keselamatan hidup mereka di dunia dan akhirat.

Dengan demikian, sistem religio-politik Islam pada hakekatnya membutuhkan sinergisitas aspek teologis dan sufistik untuk mewujudkan cita-cita dan mengaspirasi hak politik umat Islam di mana mereka bertempat tinggal dalam suatu negara guna mewujudkan kehidupan sosial-politik yang Islami dalam rangka menjadikan negara yang "baldatun țayyibatun wa rabbun gafur. []

\section{Daftar Pustaka}

Aceh, Abu Bakar, Pengantar Ilmu Tarekat Kajian Historis tentang Mistik, Solo: Ramadhoni, 1992, Cet. VII.

Allouche, Adel, The Origins and Develovment of The Ottoman Safavid Conflict 1500-1555, Michigan: Michigan University MicroFilm Internasional,1980.

al-Shaibi, Kamil Mustafa, Sufism and Shi'isme, Cet. I, England: Biddle Ltd., Guilford \& King’s Lynn, 1991. 
Anwar, A. Zuhdi, Ilmu Tasawuf Sebuah Pengantar, Jakarta: Fakultas Ushuluddin IAIN Syarif Hidayatullah, 1985, Diktat.

Baldick, Julian, Mystical Islam: An Introduction to Sufism, New York \& London: New York University Press, 1989.

Beg, M. Abdul Jabbir, Perspektif Peradaban, terjemahan, Bandung: Pustaka,1986.

Bosworth, C.E., The Islamic Dinasties: A Cronological and Geneological Handbook, Edinburgh: Edinburgh University Press, 1970.

Fathoni, Muslih, Faham Mahdi Syi'ah dan Ahmadiyah dalam Perspektif, Cet. I, Jakarta: Grafindo Persada, 1994.

Gibb, H.A.R., Shorther Encyclopedia of Islam, Leiden: Luzac and Co.Ltd., tth.

Hamka, Sejarah Umat Islam, Jakarta: Bulan Bintang, 1981, Jilid III. , Sejarah Tasawuf Perkembangan dan Pemurniannya, Jakarta: Pustaka Panjimas, 1984.

Hitti, Philip K., The History of The Arabs, London: Macmillan, 1979.

Holt, P.M., (et.al.), The Cambridge History of Islam, London: Cambridge University Press, 1970, Vol. I.A.

Jansen, G.H., Islam Militan, pentj. A. Mazhar, Bandung: Pustaka, 1983.

Kuntowijoyo, Metodologi Sejarah, Yogyakarta: Tiara Wacana, 1994.

Lambton, A.K.S. State and Government in Medieval Islam, Oxford: Oxford University Press, 1991.

Lapidus, Ira M., A History of Islamic Society, Cambridge: Cambridge University Press, 1998.

Mahmudunnasir, Syed, Islam: Its Concepts and History, New Delhi: Kitab Bhavan, 1981.

Momen, Moojan, An Introduction to Shi'i Islam, New Haven and London: Yale University Press, 1985.

Nasution, Harun, Falsafat dan Mistisisme dalam Islam, Jakarta: Bulan Bintang, 1989.

Nawawi, Hadari, Metode Penelitian Bidang Sosial,Yogyakarta, UGM Press,1993. 
, Islam Ditinjau dari Berbagai Aspeknya, Jilid, Jakarta: UI Press, 1984, Jilid I.

Nazir, Moh., Metode Penelitian, Jakarta: Ghalia Indonesia, 1988.

Nicholson, Reynold A., The Idea of Personality in Sufism, New Delhi: Idarat-i Adabiyat-i,1976.

al-Qusyairi, Abū al-Qāsim, Al-Risālah al-Qusyairiyyah fi 'Tlm al-Tasawwuf, editor: Moh.Ali Shahib, Mesir: Al-Azhar,1996.

Rakhmat, Jalaluddin, Metode Penelitian Komunikasi, Bandung: Remaja Rosdakarya, 1991.

Schimmel, Annemarie, Dimensi-dimensi Mistik dalam Islam, penterjemah Sapardi D. Damono, dkk., Jakarta: Pustaka Firdaus, 1986.

Shiddiqi, Nouruzzaman, Jeram-jeram Peradaban Islam, Yogyakarta: Pustaka Pelajar, 1996, Cet. I.

Soekanto, Soerjono, Sosiologi Suatu Pengantar, Jakarta: Rajawali, 1982.

Sudirman, M. Johan, "Politik Keagamaan dalam Islam”, Disertasi S3: Program Pascasarjana IAIN Syarif Hidayatullah, Jakarta, 1994.

Syed, Amir Ali, The Spirit of Islam, Ballimaram, Delhi: Idarah-i Adabiyat-i, 1978.

Tamara, Nasir, Revolusi Islam, Jakarta: Sinar Harapan, 1980.

Undang-Undang Dasar Republik Islam Iran, Jakarta: Kedubes Iran, 1979.

Yatim, Badri, Sejarah Peradaban Islam, Jakarta: Rajawali Press, 1996, Cet. IV. 
Abdul Syukur

halaman ini bukan sengaja dikosongkan 